\title{
Kaynaştırma Sınıfı Öğretmenlerinin Önleyici Sınıf Yönetimi \\ Becerilerinin İncelenmesi
}

\section{Bülbin Sucuoğlu*}

\author{
Pınar Ünsal **
}

Ankara Üniversitesi

\author{
Osman Özokçu***
}

\begin{abstract}
Özet
Bu çalışmanın amacı, ilköğretim okullarında kaynaştırma sınıflarında
çalışan ögretmenlerin değerlendirmektir. Çalışma grubunu bir özel ve bir devlet okulunda çalışan ve iki gruba ayrılan 59 öğretmen oluşturmuştur. Birinci grupta sınıflarında çok fazla problem davranış olduğu gözlenen ve bu davranışları çocukların özelliklerine atfeden öğretmenler, ikinci grupta ise sinıfında daha az problem davranış sergilenen ve bu davranışları çevresel uyarlamalarla kontrol edebilen öğretmenler yer almaktadır. Öğretmenlerin önleyici sınıf yönetimi becerileri öğretim ve öğretim için hazlrlık alt becerilerinden oluşan Sınıf Yönetimi Becerileri Kontrol Listesi kullanılarak değerlendirilmiştir. Çalışma sonucunda sınıfında daha fazla problem yaşayan öğretmenlerin öğretim alt ölçeği puanları ile toplam sınıf yönetimi puanları ortalamalarının diğer grubun puanlarından anlamıı düzeyde düşük olduğu bulunmuştur. Öğretime hazırlık alt ölçeğinde ise iki grubun puanları arasında fark yoktur. Ayrıca öğretmenlerin sınıf yönetimi toplam puanları ile alt ölçek puanlarının öğretmenlerin eğitimine ve okul türüne göre
\end{abstract}

\footnotetext{
* Prof. Dr., Ankara Üniversitesi, Eğitim Bilimleri Fakültesi, Özel Eğitim Bölümü, Ankara. E-posta:bulbin.sucuogludeducation.ankara.edu.tr

** Arş. Gör., Ankara Üniversitesi, Eğitim Bilimleri Fakültesi, Özel Eğitim Bölümü, Ankara.

E-posta:pinarozenmis@hotmail.com

*** Arş. Gör., Ankara Üniversitesi, Eğitim Bilimleri Fakültesi, Özel Eğitim Bölümü, Ankara.

E-posta:osman_ozokcu@hotmail.com
} 
farklılaşmadığı bulunmuştur. Araştırma bulguları ülkemizde kaynaştırma uygulamalarına ilişkin problemler açısından tartışılmıştır.

Anahtar Kelimeler: Kaynaştırma ortamları, öğretmenler, sınıf yönetimi, önleyici sınıf yönetimi becerileri

\section{Abstract}

The purpose of this study is to evaluate proactive classroom managament skills of the teachers working in the inclusive classrooms. 59 teachers from one private and one state school participated in this study and are separated to two groups. First group consists of the teachers who experienced more problem behaviors in their classrooms and attributed these problem behaviors to the characteristic of the children. On the other hand, second group of teachers experienced less problem behaviors and can make accomodations and modifications in their classroom environment to control the behaviors. Proactive Classroom Managament Skills Checklist included teaching and getting ready for teaching scales, was used for assessing managament skills of the teachers. Analysis of the data showed that the teacher who have more problems in their classroom have less total score and teaching skills score than the other group. There was no significant differences in preparing for teaching skills scale scores of the two group of teachers. Also the total scores and the both subscale scores of the teachers were not differentiated according to education of the teachers and the type of the school they work. Results are discussed in terms of the problems of the mainstreaming implementations in Turkey.

Key Words: Inclusive setings, teachers, preventive/proactive classroom managament skills.

Birçok ülkede kaynaştırma uygulamalarının artmasıyla genel eğitim sınıfları gittikçe daha heterojen sınıflar olmakta; sınıf öğretmenleri özel gereksinimli çocuklarla daha fazla karşılaşmak durumunda kalmaktadırlar. Amerika Birleşik Devletleri'nde genel olarak bir okuldaki öğrencilerin ○12-22 sinde zihinsel, duygusal ya da davranişsal bozukluklar görülmekte; ayrıca öğrencilerin \%18 inin özel gereksinimleri bulunmakta; bu öğrenciler farklı müdahale ve sağaltım programlarına gerek duymaktadırlar. Bu nedenle sınıf öğretmenleri tüm çocukların gereksinimlerini karşılayabilmek, sınıf ortamındaki her çocuğun en üst düzeyde öğrenmesini, her çocuğun kabul gördüğünü hissetmesini sağlamak için sınıf ortamında, öğretim sisteminde ve sınıf yönetiminde değişiklikler yapmak durumundadırlar (Marzano ve Marzano, 2003).

Sınıf yönetimi çok farklı şekillerde tanımlanabilmekte; tüm öğrencilerin akademik yeterliliklerinin ve kendilerine saygılarının arttığı, istendik sosyal beceriler sergiledikleri ve gittikçe bağımsızlık kazandıkları sınıflar, başarılı yönetilen 
siniflar olarak kabul edilmektedir (Long, 1999). Etkili sınlf yönetimi konusunda yapılan araştırmalar, okulda yapılacak olan başarılı her değişikliğin öğretmenin becerileri ve yeteneği ile ilişkili olduğunu ortaya koymakta; öğretmenin en önemli rolünün, iyi düzenlenmiş ve planlanmış sınıf yönetimini temel alan olumlu ve destekleyici ortam yaratmak olduğu belirtilmektedir. Öğrencilerin yeni bilgiler kazandıkları, sınıfın değerli üyesi olduklarını ve risk alma konusunda kendilerini özgür hissettikleri sınıflarda öğrenme en iyi düzeyde ortaya çıkmaktadır (Darling-Hammond, 1996; Fitzgerald ve Bass, 1997: Akt., Norris, 2003).

Geleneksel sınıf yönetimi öğrencilerin "iyi" oldukları düzeni açıklamakta; bu düzende öğrencilerin sıralarında sessizce oturarak ödevlerini yapmaları beklenmektedir. Otoriter ve öğrenciyi kontrol etmeyi temel alan bu sınıf yönetimi yaklaşımı gittikçe önemini yitirmekte; bireyin kendisini kontrol etmesini sağlayan önleyici yönetim modelleri önem kazanmaya başlamaktadır. Öğretmenler, idareciler ve öğretim ile ilgili profesyonel kuruluşlar, eski disiplin yaklaşımlarını terk etmekte; olumlu disiplin, girişimci disiplin gibi disiplin yöntemleri, bireyin fursat verildiği zaman kendini yönlendiren ve yöneten, düşünen, hisseden, problem çözen sosyal bir varlık olduğu düşüncesini temel almaktadır (Kameenui ve Darch, 1995).

$$
\text { Kounin (1971) sınıf }
$$
öğretmenlerinin bazı davranışları ile öğrenci davranışları arasındaki ilişiyi bilimsel $\begin{array}{lrr}\text { analizleri ile } & \text { sunan ilk } \\ \text { arastırmacıdır. } & \text { Kounin'e göre }\end{array}$ öğretmenin bazı davranışları ile çocukların davranışları ve öğrenmeleri arasında ciddi bir ilişki vardır. Öğretmenin çocuğu meşgul etmesi ve öğrenme etkinliklerine isteyerek katılmasını sağlaması, problem davranışların sayısını kesinlikle azaltır. Bu düşünceden hareketle sınıf yönetimi, çocuklara bıktırmayan öğrenme etkinlikleri sağlamak için uygun zamanda ve uygun şekilde kullanılan özel teknikleri içeren karmaşık bir teknolojidir (Akt., Charles, 1996). Kounin'in çalışmaları sınıf yönetimi araştırmalarının odak noktasının tepkisel stratejilerden önleyici stratejilere, öğretmenin kişiliğinden çevresel ve stratejik faktörlere dönmesine yol açmıştır. 1977'de ilköğretim düzeyinde matematik dersinde yürütülen bir çalışmada, sınıflarında akademik başarı yüksek olan öğretmenlerin daha iyi yönetim becerileri olduğu; etkinlikler arası geçişler ve disiplin problemlerine daha az zaman harcadıkları belirlenmiştir. Bu öğretmenlerin, etkinliklerin hızını ayarlayarak, net / açık yönergeler vererek ve açıklamalar yaparak öğretimsel etkinlikleri daha etkili bir şekilde yönettikleri görülmüştür (Akt., Emmer ve Stough, 2001).

Kounin'in çalışmaları yanısıra Thomas Gordon, öğrencide sorumluluk ve kendini kontrol etmeyi geliştirmeyi disiplin ile ilgili çalışmalarında odak noktası olarak almış, öğretmenlerin çocukla çalışırken kullanmaları gereken çeşitli beceriler olduğunu; bu becerilerden en önemlisinin önleyici beceriler 
olduğunu belirtmiştir. Gordon önleyici becerileri, önleyici ben mesajları, işbirliği, sınıf kurallarının oluşturulması ve katılımcı sınıf yönetiminin gerçekleştirilmesi olarak tanımlamış; sınıf kurallarının emniyetli, etkili ve uyumlu bir sınıf yaratmak için gerekli olduğunu ifade etmiştir (Charles 1996; Gordon 1974). Sinufta disiplin ve disiplin modeli geliştirmek üzere hiç çalışmamış olan Skinner'in prensiplerini temel alan davranış değiştirme yaklaşımı da 1960'lı yıllardan bu yana bazı disiplin modellerinde kullanılmıştır. Bu yaklaşım, öğretmeni çocukla destekleyici olarak çalışmak üzere yönlendirmiş; öğretmenin istendik davranış sergileyen öğrencileri $\begin{array}{lr}\text { uygun } & \text { pekiştireçlerle } \\ \text { ödüllendirmesinin, ödüllendirilen }\end{array}$ öğrencinin istendik davranışları diğerleriyle birlikte tekrarlaması ya da geliştirmesi ile sonuçlanacağını kabul etmiştir. Öğrencilerin uygun davranması ve öğrenmesi için çok uzun yıllardır kullanilan cezanin korku, hoşlanmama ve intikam isteği ortaya çıkardığı; çocukların cezalandırıldıkları zaman değil ödüllendirildikleri zaman kendilerinden ne beklendiğini daha kolay öğrendikleri düşüncesi benimsenmiştir (Charles, 1996). Önleyici disiplin yaklaşımları arasinda önemli yer tutan bir diğer yaklaşım, öğretimsel yaklaşımdır. Bu yaklaşıma göre öğretmenler çocuklara her ortamda nasıl davranmalarını istiyorlarsa (hangi

sergilemelerini bekliyorlarsa) o davranışları öğretmelidirler. Çünkü öğretmen öğretendir, genel olarak sınıf yönetimi yaklaşımlarının öğretim boyutu eksiktir ve aslında sınıf yönetimi öğretimsel yönetimdir. İstenmedik davranışlar, sosyal davranış hatalari olarak kabul edilir ve öğretmen çocuklara uygun davranışları matematik, fen ya da okumayı öğrettiği gibi öğretir. Öğretimsel yaklaşım, istenmeyen davranışların sergilenmesinden sonra tepki vermek yerine, bu davranışlarla ilişkili istendik davranışların öğretilmesi gerektiğini kabul eden önleyici bir sınıf yönetimi yaklaşımıdır (Kameenui ve Darch, 1995).

Sınıf ortamında öğretmenin davranışları ile öğrencilerin başarısı ve davranışları arasında ilişkiyi temel alan bu modellerde belirtildiği, genel olarak sınıf yönetiminin iki temel prensibi olduğu görülmektedir: a. İyi bir sınıf yönetimi tepkisel olmaktan çok önleyicidir, b. iyi bir sınıf öğrencilerin sergilemesi beklenen istendik davranışlar belirlenerek ve bu davranışlar öğretilerek yaratılır. Bu iki temel ilkeyi benimseyen öğretmenler, öğrencileri izleyerek, yardımcı geri bildirim vererek, sınıf etkinliklerinin hızını ayarlayarak ve sınıfın işleyişinin tutarlı olmasını sağlayarak kurdukları bu sistemin kalıcılığını gerçekleştirirler (Emmer ve Stough, 2001).

Kaynaştırma ortamlarında çalışan öğretmenlerin kullandığı sınıf yönetimi stratejilerini inceleyen araştırmalar oldukça azdır ve bu çalışmaların ortak bulgusu, öğretmenlerin bu konudaki sınırlılıklarını göstermektedir. Bir çalışmada öğretmenlerin tüm sınıfa öğretim yaparken, özel gereksinimli öğrenciler için bazı uyarlamalar yaptıkları ancak bu çocuklara etkili öğretim yapmak 
konusunda yetersiz olduklari bulunmuş (McIntosh, 1994), bir başka çalışmada ise (Schumm ve Vaughn, 1992) öğretmenlerin sadece \%39'unun özel gereksinimli öğrenciler için yaptıkları planlamaları yeterli bulduklarını belirttikleri görülmüştür. Blanton, Blanton ve Cross (1993) ve Hanrahan, Goodman ve Rapagna'nın (1990) çalışmalarında sınıf öğretmenlerinin özel gereksinimli öğrencilerle öğretim yaparken ortaya çıkan problem davranışlarıyla ilgili endişelerini belirttikleri görülmektedir. En etkili sinif öğretmenlerinin sınıflarındaki öğrencilerin hepsine aynı davranmadıkları, farklı öğrenciler için öğrencilerin özelliklerini temel alan farklı stratejiler kullandıkları görülmüş; bunun aksine etkili sınıf yönetimi olmayan öğrencilerinin öğretmenlerin gereksinimlerine farklı lBlanton ve diğ., 1993; Hanrahan ve diğ., 1990: Akt., Marzano ve Marzano, 2003).

Stevens (1997), sınıf ortamında öğrenme güçlüğü, dikkat dağınıklığı ve aşırı hareketıilik bozukluğu (ÖG/DDAH) olan çocukların problemlerinin ortaya çıkmaması için sınıf yönetimine ilişkin uyarlama çalışmaları yapmanın gerekliliğini vurgulamıştır. Yazar çocuğun dikkat dağınıklığı, aşırı hareketliliği ve benzeri problemlerinin azalması için tepkisel yöntemlerden söz etmemiş; sınıf ortamında yapılacak uyarlamaların bu çocukların sınıf ortamını bozan davranışlarını azaltacağını belirtmiştir. ÖG/DDAH olan çocuğun, özelliklerine uygun yere ve uygun akranı yanına oturtulması, zamanı iyi kullanması için program yapılması, düzenli olabilmesi için önlemler alınması, dikkatinin kolay ve çabuk dağılmasına neden olan uyaranların kontrolü gibi uyarlama çalışmaları ile bu problemlerle baş edeceği açıklanmış ve sınıfında ÖG/DDAH bozukluğu olan çocuklar bulunan öğretmenlerin üç aşamalı bir süreçten geçmesini önermiştir. Buna göre öğretmen 1. ÖG/DDAH olan çocuğu anlamayı ve kabul etmeyi öğrenmelidir, $\quad 2$. $\quad$ çocuğun başarısına ilişkin olumlu beklentilerini artırmalıdır, 3 . diğer çocukları kendisi gibi davranmaları konusunda yönlendirmelidir.

Carpenter ve McKee-Higgins (1996), problem davranışların kontrol edilmesinde, davranışlar ortaya çıktıktan sonra tepki vermeyi içeren geleneksel yöntemin kronik davranış problemi olan çocuklarda etkili olmadığını, grup ve bireysel olarak her öğrenci için uygun olan davranış kontrolünün önleyici olması gerektiğini, uygun davranışları fark etme ve ödüllendirmenin olumlu okul iklimi yarattığını açıklamışlardır. Yazarlara göre farklı davranış özellikleri olan öğrencilerin bulunduğu heterojen sinıflarda önleyici programlar, yetersiz olan istendik davranışların öğretimi (öğretimsel yaklaşım), olumlu sınıf iklimi, öğretmenin yürüttüğü programlar ile öğrencinin kendi davranışlarını kontrol ettiği yöntemler ve öğretmenlerin kendi aralarındaki işbirliğini içermelidir. Olumlu sınıf iklimi ise, sınıfın işleyişinin, günlük rutinlerin, kuralların, beklentilerin tutarlı olduğu, 
sosyal / sembol pekiştireçlerin kullanıldığı, olumlu davranışların ödüllendirildiği ve olumsuz/uygun olmayan davranışların görmemezlikten gelindiği, aynı zamanda programın içeriği, öğretmenin kullandığı öğretim yöntemlerinin uygun olduğu sınıf ortamı olarak belirtilmiştir.

Kaynaştırma

ortamlarında

önleyici sınıf yönetimi için,

sınıfın yapılandırılması ve etkili öğretim yapmak iki önemli nokta olarak tanımlanmıştır. Sınıfı yapılandırmak, fiziksel ortam, günlük program, öğretim yöntemi, uygun davranışları pekiştirme planı, sınıf kurallarının belirlenmesi ve uygulanmasi, uygun iletişim şekillerini bilme ve kullanmayı içermektedir. Etkili

öğretim yapmak ise sinlfin
yapılandırılması ile iç içedir ve sınıfın yapısı, hem etkili öğrenme hem de uygun olmayan davranışların sayısı üzerinde etkili bir faktördür. Bu bakış açısıyla kaynaştırma sınıflarında çalışan öğretmenlerin dikkatlerini önleyici sınıf yönetimine çekmek; "sınıfımdaki özel gereksinimli öğrencilerin uygun olmayan davranışları ne yaparsam azalır?" düşüncesinden "sınıf yönetiminde esas olan uygun olmayan davranışları önlemektir, bunun için de sınıfın yapılandırılması ve etkili öğretim yapmak önemlidir." düşüncesine geçiş yapmaları önemli görülmektedir. (Mudick ve Petch- Hogan, 1996).

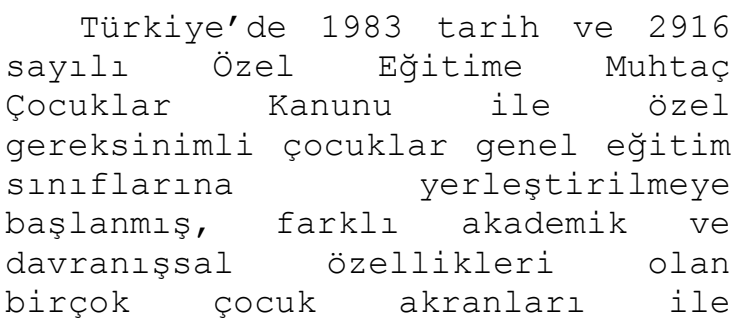

birlikte eğitim alma şansını elde etmiştir. Kaynaştırma ortamlarında çalışan sınıf öğretmenleri ile yapılan görüşmeler ve sınıflarda yapılan öznel gözlemlere göre bu ortamlarda sınıf yönetimi ile ilgili ciddi sorunlar yaşanmaktadır. Sınıf öğretmenleri özel gereksinimli öğrencilerin sergiledikleri farklı davranışları doğrudan öğrencilerin yetersizliklerine atfetmekte; bu nedenle problem davranışları azaltmak ya da kontrol etmek için daha az çaba göstermektedirler. öğretmenler özel gereksinimli öğrencilerin özelliklerini bilmemekte; sınıf yönetimi ile çocukların olumlu ve olumsuz davranışları ve başarıları arasındaki ilişkiyi fark etmemiş görünmektedirler. Öğretmenler öğretimin içeriği ile öğretim yönteminde yapılması gereken uyarlamaları bilmemekte; birçok öğretmen sınıf kurallarını ya da işleyişi öğretmemekte ve hatırlatmamaktadırlar. Batu ve Özen'in (1997), ilköğretim öğretmenlerinin sınıf kontrolüne ilişkin yaptıkları bir çalışmada öğretmenlerin problem davranışları, karşı davranışı pekiştirme, sözel uyarma, fiziksel ceza verme, etkinlikten men etme ve sınıftan dışarı çıkarma gibi tepkisel (davranış sonrası tepkiler) yöntemlerle azaltmaya çalıştıkları görülmektedir. Öğretmenlerden hiçbirisi problem davranışları azaltmak amacıyla sınıf kurallarının belirlenmesi ve öğretilmesi ya da diğer önleyici yöntemleri kullanarak kontrol etmeye çalıştıklarını belirtmemişlerdir.

Etkili sınıf yönetiminde sınıf ortaminda kabul edilebilir olumlu davranışların belirlenmesi, bu 
davranışların net açık olarak tanımlanması ve pekiştirilmesi çok önemlidir (Carpenter ve McKeeHiggins, 1996). Uysal (2001) öğretmenlerin öğrencilere pekiştireç sunma konusunda bilgi ve beceri kazandırılmasının gerekli olduğunu vurgulamaktadır. Çifci, Yıkmış ve Akbaba-Altun (2001), kaynaştırma sınıflarında çalışan öğretmenlerin pekiştireç kullanma durumlarını hem öğretmenlerle görüşme yaparak, hem de sınıflarda gözlem yaparak incelemişlerdir. Kaynaştırma öğrencileri ders sırasında silgi kalemle oynama, sıranın üzerine yatma, konuşma, kitap defter karıştırma, camdan dışarı bakma gibi davranışlar sergilemişler; öğretmenlerin büyük çoğunluğu bu davranışları kontrol etmek için çocuklara sorular sormuşlar, ancak öğrencilerin sordukları sorulara yanıt vermesinin sonunda hiçbir tepki vermeden derse devam etmişlerdir. Öğretmenlerin öğretim sırasında kaynaştırma öğrencisinin olumlu davranışlarını arttırmak için pekiştireç kullanmadıkları gözlenmiş; bazı öğretmenlerin sınıflarındaki kaynaştırma öğrencisinin farkında olmadıkları belirlenmiştir. Öğretmenler özel gereksinimli öğrencinin olumlu davranışlarını artırmak için birçok pekiştireç kullandıklarını söylemişler ancak bu ifadeler, sınıf ortamında yapılan gözlemlerin sonuçlarıyla çelişkili bulunmuştur. Çünkü kullanıldığı söylenen pekiştireçlerin hiçbirisinin sınıf ortamında kullanılmadığı gözlemler sırasında ortaya çıkmıştır.

Bir başka çalışmada, Atıcı (2001) öğretmenlerin yetkinlik düzeyleri ile sınıf yönetimi stratejileri arasındaki ilişkiyi

\begin{abstract}
incelemiş; grubundaki eleştirme, düşük yetkinlik azarlama, bağırma ve ceza gibi olumsuz yöntemleri, yüksek yetkinliğe sahip öğretmenlerin ise teşvik, uyarı, mizah, soru sorma, öğrenciye bakma ve konuşma gibi önleyici ve yapıcı yöntemleri kullandıkları bulunmuştur. Ayrıca yüksek yetkinliğe sahip öğretmenler, öğrencilerin öğrenme etkinliklerine katılımlarını sağlamada daha başarılıdırlar. Çalışmanın denekleri olan öğretmenlerin sınıflarında özel gereksinimli öğrenci olup olmadığı belli değildir ve sınıflar birer kaynaştırma ortamı olarak tanımlanmamıştır. Ancak, bu sonuçlar ülkemizde genel olarak sınıf öğretmenlerinin önleyici sinlf yönetimi becerilerine ilişkin fikir vermektedir.
\end{abstract}

$$
\text { Ağaoğlu (2001), sinıf }
$$

öğretmenlerinin karşılaştıkları istenmeyen öğrenci davranışları ve bu davranışların nedenlerine ilişkin görüşleri ile davranışları önleme yöntemlerini araştırmıştır. Arkadaşını şikâyet etme, arkadaşına bağırma, gereksiz gürültü yapma, derste izinsiz konuşma gibi öğrenci davranışlarının, öğretmenin bazı olumsuz tutum ve davranişları ile öğrencilerin kişisel özelliklerinden kaynaklandığını açıklayan Ağaoğlu, öğretmenlerin olumlu disiplini az, cezayı çok kullandıkların belirlemiştir.
Ülkemizde

ortamlarındaki önleyici sınıf yönetimi becerileri yeterince söylenebilir. becerileri hakkında bilgi sahibi olmak, kaynaştırma öğretmenlerin incelenmediği Oysa bu yeterlik 


\begin{abstract}
yetersizliklerini belirlemek öğretmenlerle yapılacak çalışmaların planlanması için çok önemlidir. Özellikle kaynaştırma sınıflarında özel gereksinimli çocukların olasi problem davranışlarının önlenmesi ve kontrol edilmesi sınıf yönetimi ile yakından ilişkilidir. Bu nedenle, bu çalışmada kaynaştırma ortamlarında çalışan öğretmenlerin önleyici sınıf yönetimi becerilerinin sınıflarında ortaya çıkan problem davranışlar, eğitimleri, çalıştıkları okul türü gibi değişkenlere göre farklılaşıp farklılaşmadığını incelemek amaçlanmıştır.
\end{abstract}

\section{Yöntem}

Bu araştırma, kaynaştırma uygulaması yapılan sınıflarda çalışan sınıf öğretmenlerinin önleyici sınıf yönetimi becerilerini değerlendirmek ve bu becerileri etkileyeceği düşünülen öğretmenlerin eğitimi (mezun oldukları okul) ve çalıştıkları okul türü değişkenlerinin ilişkisini incelemeyi amaçlayan betimsel bir çalışmadır.

\section{Çalışma Grubu}

Araştırmanın çalışma grubunu, Ankara ili sınırları içerisindeki ilköğretim okullarında çalışan 56 öğretmen oluşturmuştur. Çalışma grubunda yer alan öğretmenlerden 22'si devlet (resmi) ilköğretim okulunda, 34'ü özel ilköğretim okulunda çalışmaktadır. Öğretmenlerden 20'si Açık Öğretim Fakültesi Önlisans Programları'ndan, 18'i Eğitim Enstitüleri'nden, $\quad 18^{\prime} i$ ise herhangi bir lisans programından mezundur. Çalışma grubunu oluşturan öğretmenler, okul rehber öğretmenleri ile yapilan görüşmeler ve araştırmacıların sınıf içi gözlemleri sonucunda iki gruba ayrılmışlardır. Rehber öğretmenler ve araştırmacılar sınıf öğretmenlerini:

a. Sinıflarındaki problem davranışlarından şikâyet ederek rehberlik servisine başvurup vurmamaları (ders sırasında problem davranış sergileyen öğrencileri rehberlik merkezine getirme/gönderme, rehber öğretmeni sınıfa çağırma)

b. Sınıflarında ortaya çıkan bu problem davranışların sıklığı, bu davranışların nedenleri ile ilgili düşünceleri,

c. Problem davranışları ortadan kaldırmak amacıyla uyguladıkları çözüm yöntemlerini temel alarak gruplamışlardır. Buna göre birinci grupta (23), sınıflarında yoğun olarak problem davranış (yerinden kalkma, izinsiz konuşma, sınıf ödevlerini yapmama, sorulara yanıt vermeme, arkadaşlarına zarar verme/vurma, itme, olumsuz sözler söyleme, vb.) sergilenen, problem davranış sergilendiğinde genellikle öğrenciyi rehberlik merkezine gönderen / rehber öğretmeni sınıfa çă̆ıran öğretmenler yer almaktadır. Bu öğretmenler sinıf ortamında sergilenen problem davranışların nedenlerini genellikle öğrencilere atfetmekte; davranışları "öğrenme güçlüğü olduğu için sınıf ödevlerini yapmıyor", "hiperaktifmiş, bu nedenle sınıfta geziyor", "arkadaşlarını zarar veriyor çünkü anne babası hiç okula uğramıyor", "kimse ilgilenmediği için sorulara yanıt veremiyor" vb. ifadeleriyle tanımlayan öğretmenlerdir. Ayrıca bu öğretmenler, problem davranışları azaltmak / ortadan 
kaldırmak için anne baba ile konuşmakta, öğrenci ile bireysel konuşma yapmakta, rehber öğretmeni sınıfa çağırmakta, öğrenciyi azarlamakta ve tenefüse çıkmamak gibi çeşitli cezalar vermektedirler (Grup A). İkinci grupta (7ㄱ) yer alan öğretmenler, yukarıda örnek verilen problem davranışlarla sınıflarında daha az karşılaşmaktadırlar, bu davranışları genellikle kontrol edebilmekte ve problem davranışlar için örneğin "yerini değiştirdim ön sıraya oturtarak kontrol etmeye çalıştım", "sınıf ödevlerine yardım ettim", "konuların ona zor geldiğini biliyorum, bu yüzden dersle ilgilenmiyor", "yanına sevdiği ve birlikte çalışabileceği arkadaş oturttum ama davranış yine de devam ediyor", "birçok yöntem denememe karşın problem davranış azalmadı, başka ne yapabilirim?" açıklamaları ile okul rehberlik servisine başvurmaktadırlar (Grup B).

Araştırmacılar rehber öğretmenlerle birlikte her iki grupta yer alan öğretmenlerin sınıflarında en az bir akademik derste (Türkçe, hayat bilgisi ya da matematik) gözlem yapmışlar ve tüm gözlem sonuçlarını temel alarak, sınıflarında sık sık problem davranış ortaya çıkan, problem davranışları görmezlikten gelen ve genellikle cezalandıran ve problem davranış sergileyen çocukları rehber öğretmene gönderen öğretmenleri birinci grup olarak kabul etmişlerdir (Grup A). Problem davranışları bazen görmezlikten gelen bazen problem davranış sergileyen öğrencilere bakarak, işaret ederek davranışı kontrol etmeye çalışan ve bazen öğrencinin dikkatini çekmek için soru soran ve öğrenciye zor gelen çalışmalarda yardım eden öğretmenler ise ikinci grupta (Grup B) yer almışlardır.

Her öğretmenin sınıfında, kaynaştırma öğrencisi olarak tanı almış ya da kaynaştırma öğrencisi olarak tanı almamış ancak akademik becerileri açısından diğerlerinden belirgin derecede farklı bir ya da birden fazla öğrenci bulunmaktadır Çalışmaya katılan A ve B grubu öğretmenlerin, sınıflarında problem davranış yaşamalarına, mezun olduklarl programlara ve çalıştıkları ilköğretim okuluna göre dağılımları Tablo $1^{\prime}$ de verilmiştir.

Tablo 1

Çalışma Grubundaki Öğretmenlerin Sınıflarında Problem Davranış Yaşama ve Çalıştıkları İlköğretim Okuluna Göre Dă̆ılımları

\begin{tabular}{|l|l|l|l|}
\hline \multirow{2}{*}{$\begin{array}{l}\text { Mezun Okul } \\
\text { Okdukları }\end{array}$} & $\begin{array}{l}\text { Sınıf Öğretmeninin } \\
\text { Yaşaması }\end{array}$ & \multirow{2}{*}{ Toplam } \\
\cline { 2 - 4 } & $\begin{array}{l}\text { Problem Davranı } \\
\text { Yaşıyor (Grup A) }\end{array}$ & $\begin{array}{l}\text { Problem Davranış } \\
\text { Yaşamıyor (Grup B) }\end{array}$ & \\
\hline Özel Okul & 10 & 24 & 34 \\
\hline Devlet Okulu & 3 & 19 & 22 \\
\hline Toplam & 13 & 43 & 56 \\
\hline
\end{tabular}




\section{Veri Toplama Araçları}

Bu çalışmada veri toplamak amacıyla Sınıf Yönetimi Becerileri Kontrol Listesi (SYBKL) kullanılmıştır. SYBKL, kaynaştırma uygulamasi yapilan siniflarda çalışan sınıf öğretmenlerinin "önleyici sınıf yönetimi becerilerini" değerlendirmek amacıyla araştırmacılar tarafından geliştirilmiştir. Öncelikle alanyazında sınıf yönetimi konusunda yapılan çalışmalar taranmış (Atıcı 2001; Banu ve Özen 1997; Murdick ve Petch-Hogan, 1996) ve sınıf yönetimi becerilerini kapsayan bir madde havuzu oluşturulmuştur. Bu madde havuzunda öğretmenlerin olumsuz davranışlarla baş etmek için kullandıkları stratejileri / yöntemleri açıklayan maddelere (uyarma, bağırma, ceza verme, eleştirme, azarlama, etkinlikten men etme, vb..) yer verilmemiştir. Bunun yerine, alan yazında etkili ve önleyici sinıf yönetimi kapsamında ele alınan olumlu davranışları ödüllendirme, uygun yönerge verme, derse uygun başlama, dersi uygun bitirme, geçişleri planlama, sınıf kurallarını oluşturma ve öğretme ile dersin amacina uygun materyal kullanma gibi önleyici sınıf yönetimi becerileri yer almıştır. 18 maddenin her birinde açıklanan sınıf yönetimi becerisi, değerlendirmeyi kolaylaştırmak amacıyla gözlenebilir şekilde açık ve net olarak tanımlanmıştır. İlk formla ilgili geçerlilik ve güvenirlik çalışmaları aşağıda açıklanmıştır.

\section{Geçerlik} çalışmaları: önleyici sınıf yönetimi becerileri gözlenerek doldurulan SYBKL'nin geçerlik çalışması olarak faktör analizi çalışmaları yapılmış, aracın güvenirliğini belirlemek için yapılan iç tutarlılık çalışmasında madde toplam korelasyonları hesaplanmıştır.

Faktör Analizi: SYBKL'nin yapı geçerliğini belirlemek amacıyla 18 maddelik ilk kontrol listesi için ilk olarak, maddelerin kuramsal yapıları göz önüne alınarak bir faktöre göre Temel Bileşenler Analizi yapılmıştır. Bu ilk analiz sonucunda 3 maddenin faktör yüklerinin 30'dan düşük olması nedeniyle bu maddeler kontrol listesinden Çıkarılmıstır. Daha sonra 15 maddelik yeni kontrol listesi için yapılan ikinci faktör analizi (Varimax Dik Döndürme Tekniği) sonucunda, SYBKL inde yer alan maddelerin iki faktöre dağıldığı ve faktör $1^{\prime}$ in toplam varyansin $\% 30.72^{\prime}$ sini, faktör 2'nin \%18.27"sini açıkladığı görülmüştür. Bu iki faktörde yer alan maddelerin kuramsal içerikleri göz önüne alınarak faktör $1^{\prime}$ de yer alan 10 madde Öğretim Sürecine İlişkin Maddeler; faktör 2'de yer alan 5 madde ise öğretim Hazırlığına İlişkin Maddeler olarak kavramsallaştırılmıştır. Faktör 1'de yer alan maddelerin faktör yük değerleri .28 - .81; faktör 2 'de yer alan maddelerin faktör yük değerleri ise $-.51 \quad-75$ arasında değişmektedir. Madde faktör yükleri .30 dan daha az olan maddeler, kontrol listesinden çıkarıldığı halde, "öğretmenin sınıf kurallarını hatırlatması" ile ilgili olan madde, faktör yükü .28 olduğu halde önemli görülerek, kontrol listesinde kalmasına karar verilmiştir. 


\begin{abstract}
Öğretim Sürecine ilişkin maddelerden oluşan birinci

faktörde: öğretmene ilişkin sınıf kurallarını sık sık hatırlatıyor mu?, sınıf kurallarını öğretiyor mu?, derse uygun başlıyor mu?, derste verdiği yönergeler uygun mu?, öğretime başlamadan önce öğrencilerin dikkatini çekiyor mu?, derste verdiği yönergeler uygun mu?, derste yardım ve ipucu kullanıyor mu?, pekiştireçleri uygun kullanıyor mu?, ders içinde farklı etkinliklere yer veriyor mu?, aynı anda bütün sınıfı kontrol edebiliyor mu?, dersi uygun şekilde bitiriyor mu? maddeleri yer almaktadır. İkinci faktör 5 maddeden oluşmaktadır ve bu faktörde yer alan öğretim Hazırlığı'na ilişkin maddeler sırasıyla şunlardır: Öğretmen ders içeriğini çocuklara göre uyarlıyor mu?, her ders başında gerekli materyalleri hazırlıyor mu?, etkinlikler arası geçişleri haber veriyor mu?, ders süresini uygun kullanıyor mu?, kullandığı değerlendirme yöntemi uygun mu? .
\end{abstract}

Güvenirlik Çalışması: Aracın güvenirliğini belirlemek için yapılan çalışmada, Cronbach-Alpha katsayısı .86, faktörlere ilişkin alpha katsayıları ise birinci faktör için .85 ve ikinci faktör için.54 olarak bulunmuştur. Kontrol listesinin birinci faktörü ve toplam 15 madde için bulunan Alpha iç tutarlılık katsayıları yüksektir, ancak ikinci faktörün alpha değerinin daha düşük olmasının bu faktörde yer alan madde sayısıyla ilişkili olduğu düşünülmektedir. Bir ölçme aracının güvenirlilik katsayısının genellikle $.70-.80$ olması durumunda, o aracın araştırmalarda kullanılması için yeterli olduğu kabul edilmektedir ve bir ölçme aracının güvenirliliği, madde sayısı ile ilişkilidir. Buna göre ölçme aracındaki madde sayısının artırılması ölçülen niteliklerin temsil edici özelliğini de artıracak ve güvenirliliğini yükseltecektir (Özgüven, 1994). Ölçekte yer alan madde sayısı az ancak, maddelerin faktör yük değerleri, madde-faktör korelasyonları yüksek ise güvenirlik katsayısındaki düşüş daha az olacaktır (Tabachnick ve Fidel, 2001). SYBKL'nin ikinci faktöründe yer alan maddelerin faktör yükleri ve madde toplam korelasyonları kabul edilebilir düzeydedir. Bu nedenle ikinci faktör için .54 olan Alpha katsayısının yeterli olduğu düşünülebilir.

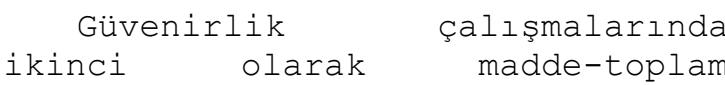
korelasyonları hesaplanmıs ve en düşük madde-toplam korelasyonu .31, en yüksek korelasyon katsayısı ise .67 olarak belirlenmiştir. Sadece 15. maddenin madde-toplam korelasyonu .30 dan düşüktür. Tüm maddelerin madde toplam korelasyonları .000 düzeyinde anlamlıdır. Tüm analizler sonucunda elde edilen verilerin aracın geçerli ve güvenilir olduğunu gösterdiği kabul edilmiş ve bu nedenle 15 maddeden oluşan son hali verilmiştir.

Kontrol listesinde yer alan her madde evet(2), bazen(1) ve hayır(0) olmak üzere üçlü dereceleme ile değerlendirilmiştir. Her öğretmenin kontrol listesinden alabileceği en yüksek puan 30, en düşük puan ise sıfırdır. Puanların artması öğretmenlerin önleyici sınıf becerilerinin arttığını, azalmasi ise bu becerilerin 
azaldığını SYBKI' nin maddeleri göstermektedir. ile madde toplam korelasyonları Tablo 2'de verilmiştir. Yapılan geçerlik ve güvenirlik çalışmaları sonucunda "Sınıf Yönetimi
Becerileri Kontrol Listesi"nin öğretmenlerin sınıf yönetimlerini güvenilir şekilde değerlendirdiği söylenebilir.

Tablo 2

SYBKL'nin Faktör Yapısı, Madde ve Toplam Korelasyonları

\begin{tabular}{|c|c|c|c|c|c|}
\hline \multirow[t]{2}{*}{ Maddeler } & \multirow{2}{*}{$\begin{array}{l}\text { Döndürme } \\
\text { Öncesi } \\
\text { Faktör } 1 \\
\text { Yük Değerleri }\end{array}$} & \multicolumn{2}{|c|}{\begin{tabular}{|l} 
Varimax Dik \\
Döndürme
\end{tabular}} & \multirow[t]{2}{*}{$\begin{array}{l}\text { Faktör } \\
\text { Ortak Varyansı }\end{array}$} & \multirow{2}{*}{$\begin{array}{l}\text { Madde Toplam } \\
\text { Korelasyonlar } \\
\text { I }\end{array}$} \\
\hline & & Faktör 1 & $\begin{array}{l}\text { Faktör } \\
2\end{array}$ & & \\
\hline $3(1)$ & .36 & .28 & .26 & & .31 \\
\hline $4 \quad(2)$ & .65 & .52 & .41 & & .58 \\
\hline $5(3)$ & .76 & .67 & .35 & & .63 \\
\hline $6(4)$ & .44 & .17 & .75 & & .53 \\
\hline $7 \quad(5)$ & .27 & & .75 & & .44 \\
\hline $8 \quad(6)$ & .73 & .81 & & & .64 \\
\hline $9(7)$ & .67 & .67 & .14 & & .58 \\
\hline $10(8)$ & .54 & .43 & .34 & & .44 \\
\hline 11 (9) & .57 & .69 & & & .54 \\
\hline $12(10)$ & .72 & .66 & .29 & & .66 \\
\hline $13(11)$ & .71 & .54 & .57 & & .45 \\
\hline $14(12)$ & .68 & .69 & .13 & & .58 \\
\hline $15 \quad(13)$ & .61 & .39 & .64 & & .53 \\
\hline $16(14)$ & .68 & .73 & & & .57 \\
\hline $18(15)$ & .13 & .34 & -.51 & & -.21 \\
\hline
\end{tabular}

\section{Verilerin Toplanması ve Analizi}

Çalışma grubunda yer alan öğretmenlerin önleyici sınıf yönetimi becerileri, Yönetimi Becerileri Listesi kullanilarak değerlendiriciler değerlendirilmiş; kontrol listesi kullanılarak toplanan verilerin güvenirliği gözlemler arası güvenirlik yöntemi ile incelenmiştir.

\section{Gözlemlerarası}

güvenirlik: Çalışma grubunda yer alan öğretmenlerin önleyici sınıf yönetimi becerileri bir araştırmacı ve iki değerlendirici tarafından değerlendirilmiştir. Değerlendiriciler, bu çalışmanın yürütüldüğü projede gönüllü olarak çalışan, değerlendirdikleri sınıf öğretmenlerini çok iyi tanıyan ve arastırmacilar ile sinıflarda birçok değerlendirme çalışmasına katılmış olan gönüllü son sınıf lisans öğrencileridir. ìlk 
aşamada araştırmacılar, lisans öğrencileri ile üç saat süren bir toplantı yapmışlardır. Bu toplantıda, kontrol listesinde yer alan her madde ayri ayrı açıklanmış ve SYBKL'sini nasıl kullanacakları, her bir beceriyi nasıl değerlendirecekleri anlatılmıştır. İkinci aşamada ise değerlendiriciler bir ay arayla her sınıfta birbirinden bağımsız iki gözlem yapmışlar, böylece her öğretmenin önleyici sınıf yönetimi becerileri iki kez ve aynı gözlemciler tarafindan değerlendirilmiştir. Gözlemcilerin yaptıkları iki değerlendirme sonucunda toplanan veriler üzerinden hesapladıkları puanlar arasındaki korelasyonun ortalaması .87 olarak bulunmuştur. Bu değerin öğretmenlerin sınıf yönetimi becerilerinin güvenilir şekilde toplandığını düşündürmektedir.

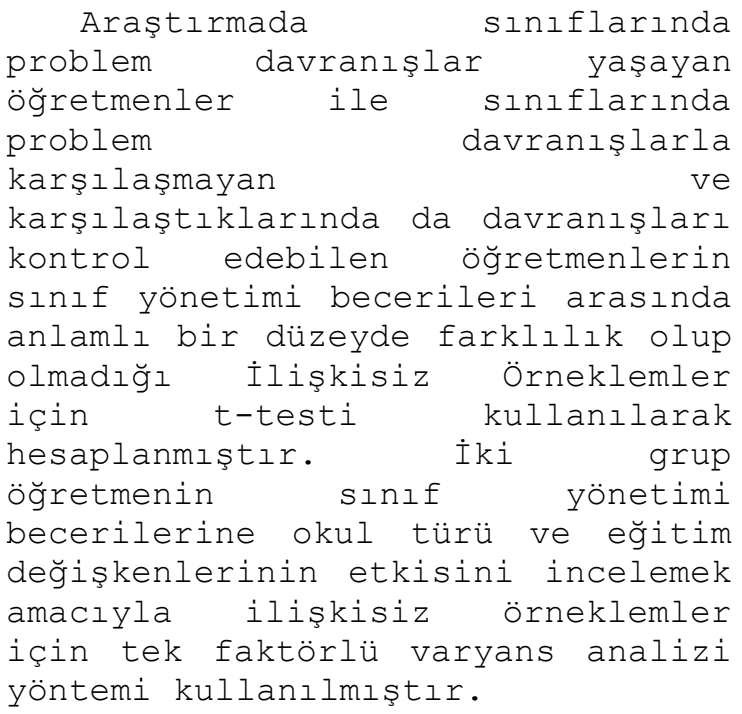

siniflarinda la ve karsılastıklarında da davranışları kontrol edebilen öğretmenlerin sınıf yönetimi becerileri arasında anlamlı bir düzeyde farklılık olup olmadığı İlişkisiz Örneklemler için t-testi kullanılarak hesaplanmıştır. İki grup ogretmenin sinlf değişkenlerinin etkisini incelemek örneklemler yöntemi kullanılmıştır.

\section{Bulgular}

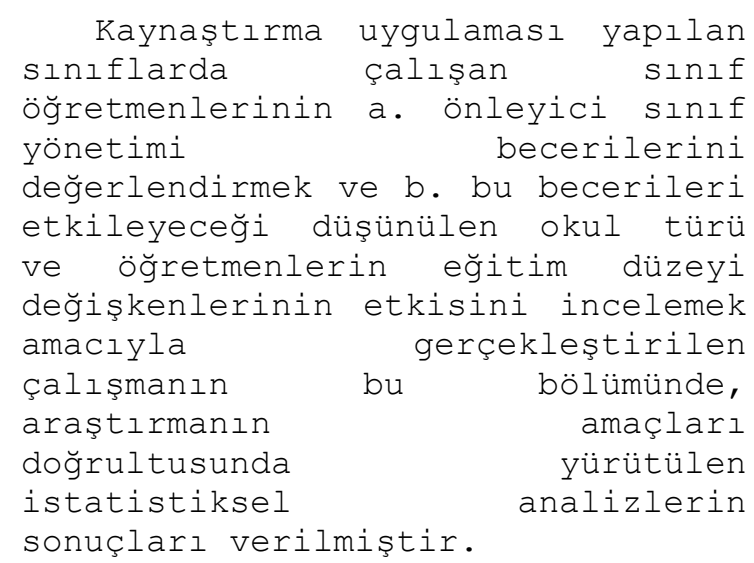

1) Sınıf öğretmenlerinin önleyici sınıf yönetimi becerilerinin belirlenmesi: Grup A ve Grup B nin SYBKL den aldıkları toplam puan ve öğretime sürecine ilişkin maddelerden oluşan 1. faktör puanları arasinda istatistiksel olarak anlamlı bir fark olduğu görülmüştür. ( $t=3.03$; $\mathrm{p}<.05) \quad \dot{I} k i$ grubun öğretim hazırlığına ilişkin maddelerden oluşan 2. faktör puanları arasında anlamlı bir fark ortaya çıkmamıstır. $\quad(t=1,79 ; \quad p=.07)$. Tablo 3 incelendiğinde sınıfında problem davranış yaşamayan ve problemleri kontrol edebilen öğretmenlerin, toplam puan $(x=20.30)$ ve 1 . faktör puanları ortalaması $(x=13.83), \quad$ sınıfındaki problem davranışları öğrencilere atfeden öğretmenlerden anlamlı derecede daha fazla olduğu görülmektedir.

\section{Tablo 3}

İki Grup Öğretmenin SYBKL Puanları Arasındaki Farkın Anlamıılı̆̆ı İÇin TTesti. 


\begin{tabular}{|l|c|c|c|c|c|c|}
\hline \multirow{2}{*}{ Faktörler } & \multicolumn{2}{|c|}{ Grup A } & \multicolumn{2}{c|}{ Grup B } & & \\
\cline { 2 - 7 } & $\mathrm{x}$ & SS & $\mathrm{x}$ & $\mathrm{SS}$ & $\mathrm{t}$ & $\mathrm{p}$ \\
\hline Faktör 1 & 9.08 & 5.33 & 13.83 & 4.63 & $\mathbf{3 . 0 3}$ & $.05^{\star}$ \\
\hline Faktör 2 & $\mathbf{5 . 1 6}$ & 2.94 & 6.47 & 1.99 & 1.79 & .07 \\
\hline Toplam Puan & 14.25 & $\mathbf{8 . 0 1}$ & 20.30 & 5.82 & $\mathbf{2 . 9 1}$ & .05 * \\
\hline
\end{tabular}

2) Önleyici sınıf yönetimi becerilerinin eğitimine göre farklılaşmadığının öğretmenlerin farklılaşıp incelenmesi: Grup A ve Grup B de yer alan öğretmenler tek grup olarak ele alınarak, önleyici sınıf yönetimi becerilerinin mezun oldukları okula (açık öğretim fakültesi, eğitim enstitüsü, diğer lisans programları) göre farklılaşıp farklılaşmadığı tek yönlü varyans analizi ile incelenmiş; çalışma grubu öğretmenlerinin faktör 1 , faktör 2 ve toplam puanlarının eğitimlerine göre farklılaşmadığı bulunmuştur $[\mathrm{F}$ toplam $(2,51)$ $=.908, \quad \mathrm{p}>.41 ; \quad \mathrm{F} 1(2,51)=.40 .1$, $\mathrm{p}>.22 ; \quad \mathrm{F} 2(2-51)=.108, \mathrm{p}>.89]$.

$\begin{array}{lrr}\text { 3) Önleyici } & \text { sınıf yönetimi } \\ \text { becerilerinin çalışılan ör okul } \\ \text { türüne före } & \text { farklılaşıp } \\ \text { farklılaşmadığın } & \text { incelenmesi: }\end{array}$

Çalışmada son olarak çalışma grubunun önleyici sınıf yönetimi becerilerinin çalıştıkları okul türüne göre farklılaşıp farklılaşmadığı araştırılmış ve analiz sonuçları Tablo 4'de verilmiştir. Tablo 4'de görüldüğü gibi; yapılan $t$ testi sonuçlarına göre devlet okulunda ve özel okulda çalışan öğretmenlerin hem toplam puan ortalamaları $(t=.93$, $p>.36)$ hem de faktör $1 \quad(t=1.02$, $p>.31)$ ve faktör 2 den $(t=.475$, p>.64) elde ettikleri puanların ortalamaları arasında anlamlı bir fark olmadığı bulunmuştur.

Tablo 4

İki Grup Öğretmenin Çalıştıkları Okul Türüne Göre SYBKL Puanları Arasındaki Farkın Anlamlılığı íçin T-Testi Sonuçları

\begin{tabular}{|l|c|c|c|c|c|c|}
\hline \multirow{2}{*}{ Faktörler } & \multicolumn{2}{|c|}{$\begin{array}{c}\text { Devlet Okullarında } \\
\text { Çalışan öğretmenler }\end{array}$} & $\begin{array}{c}\text { Özel Okulda Çalışan } \\
\text { Öretmenler }\end{array}$ & & \\
\cline { 2 - 7 } & $\mathrm{x}$ & $\mathrm{SS}$ & $\mathrm{x}$ & $\mathrm{SS}$ & $\mathrm{t}$ & $\mathrm{p}$ \\
\hline Faktör 1 & 13.63 & $\mathbf{4 . 6 8}$ & 12.18 & 5.53 & 1.017 & .314 \\
\hline Faktör 2 & 6.36 & 1.98 & 6.06 & 2.47 & .475 & .637 \\
\hline Toplam Puan & 20.00 & 5.80 & 18.25 & 7.38 & .930 & .356 \\
\hline
\end{tabular}

\section{Tartışma}

$\mathrm{Bu}$ çalışmada $\sin I f$ öğretmenlerinin önleyici disiplin becerileri incelenerek, iki grup sınıf öğretmeninin sınıf yönetimi becerileri arasında fark olup olmadığı belirlenmeye çalışılmıştır. Çalışmada öğretmenlerin sınıf yönetimi becerileri iki faktörlü yapısı olan Sınıf Yönetimi Becerileri 


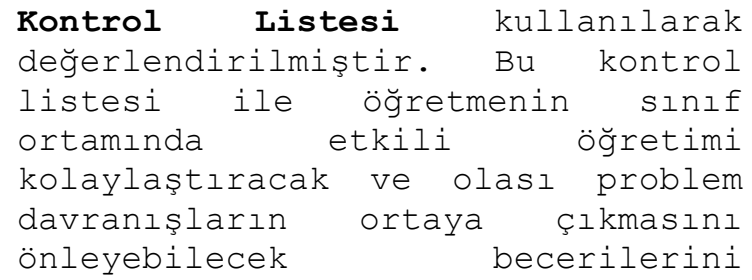
değerlendirmek amaçlanmıştır.

Araştırmanın çalışma grubunu iki grup öğretmen oluşturmuştur. Birinci grupta yer alan öğretmenler, sınıfında çok problem davraniş sergilenen, bu davranışlardan sürekli şikâyet eden ve problem davranişları öğrencilerin özelliklerine atfeden öğretmenlerdir. İkinci grup öğretmenler ise sınıflarında daha az problem davranış ortaya sergilenen ve genellikle bu problemleri kontrol edebilen öğretmenlerdir. Çalışmanın birinci bulgusu doğrudan öğretmenlerin bu özellikleri ile ilgilidir ve iki grup öğretmenin önleyici sınıf yönetimi becerilerinin birinci faktör ve kontrol listesinin tümünden elde edilen toplam puanlarında anlamlı düzeyde farklılaştığı görülmüştür. Sınıflarında çok fazla problem davranış sergilenen ve bu davranışları öğrenci özelliklerine atfeden öğretmenlerin öğretim sürecine ilişkin puanları ortalamasi ile toplam puanlarınin ortalamasının diğer grubun puanları ortalamalarından anlamlı bir şekilde azdır.

Önleyici sınıf yönetimi becerileri öğretmenin etkili öğretim yapabilmesi, olumlu sınıf iklimi yaratması ile ilgilidir ve önleyici davranış kontrolü için gerekli olan becerileri kapsamalıdır (Carpenter ve McKeeHiggins, 1996). SYBKL'nin birinci faktöründe yer alan maddeler bu özelliklere sahip maddelerdir ve aynı zamanda her öğretmenin sınıfı/öğretimi yapılandırma ve etkili öğretim yapma becerileri ile doğrudan ilişkilidir. Sınıfı yapılandırma becerisi fiziksel ortamın düzenlenmesi, günlük program, öğretim yöntemi, uygun davranışları pekiştirme planı, sınıf kurallarının belirlenmesi ve uygulanması, uygun iletişim şekillerini bilme ve kullanma becerilerini içerir ve sınıfın yapısı uygun olmayan davranışların sayısı üzerinde etkilidir (Mudick ve Petch- Hogan, 1996). Bu nedenle çalışmanın birinci bulgusu, bir sinifta sergilenen problem davranışların sayısının çok olması, öğretmenin sınıf yönetimi becerilerine ilişkin sorun olduğunu düşündürebilir. Çünkü etkili öğretmenlerin sınıfları, iyi yönetilen ve daha az sayıda problem davranış sergilenen, öğrencilerin verilen görevleri sürdürdüğü ortamlar olarak tanımlanmakta ve etkili olmayan öğretmenlerin bu becerilerinin yetersiz olduğu belirtilmektedir. (Colville-Hall, 1999). Bu nedenle öğretmenlerin davranışlara etki eden çevresel faktörler (sınıf ortamı, öğretim yöntemi, pekiştireçler vb.) ve öğrenci davranışları ile öğretmen davranışlarının ilişkisi konularında bilgilendirilmesi ile özellikle kaynaştırma uygulamalarının yürütüldüğü ortamlarda sergilenen birçok davranış probleminin azalacağı düşünülmektedir

(http://www.slc.sevier.org/inclhav .htm) .

Çalışmaya katılan iki grup öğretmenin SYBKL'nin ikinci faktöründen elde ettikleri puanların ortalamaları arasında anlamlı bir fark yoktur. Ancak bu 


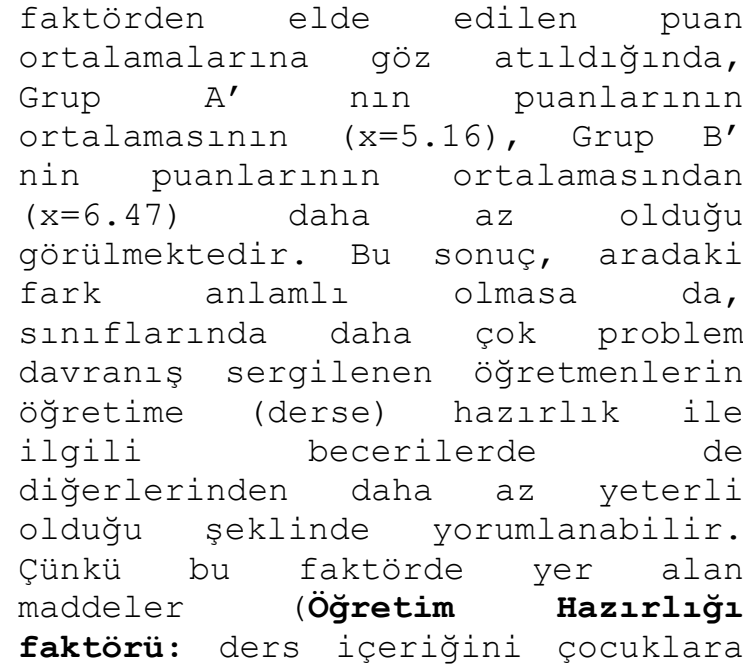
göre uyarlama, her ders başında gerekli materyalleri hazırlama, etkinlikler arası geçişleri haber verme, ders süresini uygun kullanma, kullandığı değerlendirme yönteminin uygun olup olmaması), hem etkili öğretim hem de davranış kontrolü için önemli becerileri göstermektedir. Kaynaştırma uygulamalarında öğretim içeriğini sınıftaki her öğrenciye uyarlayabilmek çok temel bir beceridir ve kaynaştırma programlarının başarısını artıran bir faktör olarak kabul edilmektedir. Öğretmenin öğretim yöntemleri öğrencinin öğrenme stiline uygun değilse, bu durum problem davranışların sergilenmesine yol açabilmektedir. öğrencilerin tüm problem davranışları, uygulanan programın içeriğine ya da sınıfta kullanılan öğretim yöntemlerine atfedilemese de, öğrenci için uygun olmayan program içeriği (içeriği öğrenci için çok kolay ya da çok zor olan program) ve öğretim stratejileri problem davranışların ortaya çıkmasına katkıda bulunan faktörlerdir. Bazı problem davranışlar öğretmenin çocuğun farklı gereksinimlerini karşılayamamasına bağlı olarak ortaya çıkabilir. Öğrenci öğretilen kavramları farklı ortamlara transfer edemiyorsa, öğretilenleri anlayamıyorsa ve takip edemiyorsa bu durum da çeşitli istenmeyen davranışlarla sonuçlanmaktadır.

(http://www.slc.sevier.org/inclhav . htm).

Sınıf öğretmeninin ders süresini uygun kullanması, sürenin öğretim, tekrar ve değerlendirme etkinlikleri için planlanması, her öğrencinin

kolaylaştıracak materyallerinin kaynaştırma öğrenmesini öğretim kullanılması başarısını artırmaktadır. Stevens (1997), öğrenme güçlüğü, dikkat eksikliği ve aşırı hareketlilik bozukluğu olan çocuklar için zamanın iyi planlanmasi ve etkinliklerin düzenlenmesinin bu çocukların başarısını artırdığını belirtmektedir. Murdick ve PetchLogan (1996) ise, etkili öğretim yapılabilmesi için sınıfın yapılandırılması gerekliliğini açıklamışlar ve fiziksel ortam, günlük program, öğretim özellikleri, ödüllendirme sistemleri ve sınıf kuralları ile ilgili düzenlemeleri çevresel düzenlemeler olarak açıklamışlardır. Geçişlerini planlayan, öğretim hızını öğrencilerin özelliklerine göre ayarlayan, öğrencilerin öğretilecek konu ya da kavram için ön koşul becerilere sahip olup olmadıklarını inceleyen ve etkili öğretim yapan öğretmenlerin sınıflarında problem davranışların daha az çıkacağını belirtmişler, etkinlikler arası geçişin planlanmasını, öğretim elemanlarından birincisi olarak bildirmişlerdir. Bu çalışmada 
kullanılan SYBKL'de bu becerileri ifade eden maddeler bulunmasina karşın, her maddeye ilişkin analizler yapılmaması nedeniyle, geçişler, sınıf kuralları ya da öğretimi uyarlama becerilerine ilişkin bulgulara yer verilememiştir. Ancak çalışma sirasinda yapılan öznel gözlemlerde, genel olarak öğretmenlerin genellikle geçişleri planlamadıkları, ders başlarken yapilacak etkinlikleri ve geçişleri haber vermedikleri, dolayısıyla geçişlerde daha fazla karmaşanın yaşandığı gözlenmiştir. Ayrıca öğretmenlerin çoğunun sınıf kurallarını belirlemedikleri ya da belirleseler bile bu kuralları öğretmedikleri, sadece kurallara uymayanları ikaz ettikleri görülmüştür. Daha sonra yapılacak olan çalışmalarda öğretmenlerin önleyici sınıf yönetimi becerilerinin ayrıntılı olarak belirlenmesine sağlayacak gözlemlerin ve analizlerin yapılması önerilmektedir.

Long, Biggs ve Hinson (1999) öğretmen adayları ve deneyimli öğretmenlerle yaptığı bir çalışmada katılımcılara a. sınıf yönetimine katkısı olan faktörlerin neler olduğunu b. öğretmenin hangi özelliklerinin sınıf yönetiminde önemli olduğunu sormuslardır. Yanıtlara bakıldığında hem aday öğretmenler hem de deneyimli öğretmenlerin yaklaşık o50'si branşlarından bağımsız olarak sınıf yönetimini öğretmenle ilişkili bulmuşlardır. Aday öğretmenlerin ortalama 25i, deneyimli öğretmenlerin ise $\% 12^{\prime} \mathrm{si}$ öğrencilerin özelliklerini sınıf yönetimini etkileyen faktör olarak seçmişlerdir. Sınıf yönetimine etki eden temel faktör olarak öğretmen ve öğretmenlerin bilgisi, sabrı, meraklı olması ve kişiliği gibi özellikler belirlenmiş olmasına karşın, bu çalışma sırasında, sınıflarında daha çok problem sergilenen öğretmenlerin, bu problem davranışlarını genellikle öğrencilerin özelliklerine atfettikleri gözlenmiştir. Çalışmada bu gözleme ilişkin doğrudan bulgu elde edilmemesine karşın, bu öğretmenlerin sınıf yönetimini doğrudan çocukların özellikleri ile ilişkilendirdikleri, bu nedenle problem davranışları önlemek amacıyla sınıf yönetiminde, öğretimde değişiklik yapmak yerine problemi rehber öğretmenlerin çözmesini bekledikleri düşünülebilir.

Çalışmada

ikinci

olarak

öğretmenlerin mezun oldukları eğitim programının sınıf yönetimi becerilerinde farklılığa yol açıp açmadığı incelenmiştir. Sınıf yönetimi becerileri değerlendirilen öğretmenler mezun oldukları okula / programa göre üç gruba ayrılmışlardır. Birinci grupta açık öğretim fakültesinden ön lisans diplomasi olan öğretmenler, ikinci grupta eğitim enstitüsü mezunu olan öğretmenler yer almıştır. Üçüncü grup öğretmenler ise herhangi bir lisans programından mezun olan öğretmenlerdir. Çalışmanın başlangıcında eğitimdeki bu farklılığın sınıf yönetimi becerilerine yansıyacağı ve eğitim enstitülerinden mezun olan öğretmenlerin sınıf yönetimi becerilerinin daha fazla olacağı beklenmistir. Ancak analiz sonucunda, bu beklentinin aksine, üç grup öğretmenin ölçeğin tümünden aldıkları hem toplam hem de faktör puanlarının anlamlı düzeyde farklılaşmadığı 
bulunmustur. Bu saşrtıc bir sonuçtur çünkü herhangi bir lisans programindan mezun olan öğretmenlerin sınıf yönetimi becerilerinin diğer öğretmenlerden farklılaşmadığını göstermektedir. Dolayısıyla belki de öğretmen yetiştiren kurumlarda verilen sinıf yönetimi derslerinin içeriğinin incelenmesi gerekecektir. Aynı zamanda hangi eğitim programını tamamlamış olurlarsa olsunlar, öğretmen adaylarının kazanmaları gereken en temel beceriler arasında önleyici sınıf yönetimi becerilerinin de yer alması gerektiği söylenebilir.

Araştırmada son olarak, öğretmenlerin sinıf yönetimi becerilerinin okulun özelliğine göre değişip değişmediği incelenmiş, devlet okulunda ve özel okulda çalışan öğretmenlerin sınıf yönetimi becerilerinin hem toplam puanlarda hem de faktör puanlarında farklılaşmadığı görülmüştür. Bu sonuç, iki farklı okulda çalışan öğretmenlerin sınıf yönetimi becerilerinin aynı/benzer olduğunu göstermektedir. Oysa özel okullar, öğretmenleri için özel okul felsefesi ve amacina uygun birçok hizmet içi eğitim programları düzenlemekte, bu programlar doğrudan sınıf yönetimi ile ilgili olmasa da, öğretmenler öğretim yöntemleri ve teknikleri konularda birçok çağdaş/yeni bilgi edinmektedirler. Devlet okullarında çalışan öğretmenlerin katıldığı hizmet içi programlar ise daha sınırlı sayıdadır. Bu nedenle devlet okulu ve özel okul öğretmenlerinin sınıf yönetimi becerilerinin farklılaşmaması, olumlu ve olumsuz olarak iki şekilde tartışılmalıdır. Daha az hizmet içi programına katılan öğretmenlerin önleyici sınıf yönetimi puanlarının, daha fazla seminer, toplantı ya da hizmet içi eğitime katılan öğretmenlerin puanlarından farklılaşmaması olumlu; daha fazla bilgi ve beceri kazanma şansı; olanağı bulunan özel okul öğretmenlerinin puanlarinin devlet okulu öğretmenlerinin puanlarından farklılaşmaması ise olumsuz olarak düşünülebilir.

Bu çalışmada göz önüne alınması gereken birkaç sınırlık bulunmaktadır. Birincisi, SYBKL'nin faktör analizi çalışmalarının az sayıda (toplam 56 öğretmen) öğretmenden toplanan verilerle gerçekleştirilmiş olmasıdır. Sınıf içi gözlemlerin uzun zaman alması, bağımsız değerlendiricilerin daha fazla sayıda öğretmenin becerilerinin gözlemek için yeterli zamanlarının olmaması bu sınırlılığı yaratmıştır. Çalışmaya katılan her öğretmenin sınıfında en az bir akademik ders gözlem yapılması bu sürenin artmasına neden olmuş ve çalışma, ulaşılabilen iki okulun öğretmenleri ile sinırlı tutulmuştur. Daha sonra yapılacak çalışmalarda daha fazla sayıda ve farklı özelliklerde (branş öğretmenleri, orta öğretim öğretmenleri vb.) öğretmenin sınıf yönetimi becerilerinin değerlendirilmesi SYBKL'nin psikometrik özelliklerine ilişkin daha güvenilir bilgiler verecektir.

İkinci sınırlılık, SYBKL'nin faktör yapısına ilişkindir. Faktör analizi çalışmalarında SYBKL'nin tek faktörlü bir yapıda olabileceği ve bu tek yapının kontrol listesinde yer alan tüm maddeleri (önemli sınıf yönetimi becerilerini) içereceği düşünülmüştür. Ancak tek faktörlü 


\begin{abstract}
yapı sınandığında, bu yapının toplam varyansın 035 ten azını açıkladığı görülmüştür. Analizlerde faktör sayısının yüksek tutulması, faktörleri isimlendirme ve anlamlandırmada güçlük yaşansa da, açıklanan varyansı artırır. Açıklanan varyansın yüksek olması, ilgili yapının ya da kavramın daha iyi ölçüldüğünün bir göstergesi olarak yorumlanır (Büyüköztürk, 2002). Bu nedenle çalışmada tek faktörlü yapı yerine iki faktörlü yapı kabul edilmiştir.
\end{abstract}

Çalışmanın üçüncü sınırlılığı olarak SYBKL ile toplanan verilen güvenirliliğinin "gözlemciler arası güvenirlilik" hesaplanması yerine "gözlemler arası güvenirlilik" yönteminin kullanılmasıdır. Bağımsız değerlendiricilerin az sayıda olmasi nedeniyle, bir sinifta gözlem yapmak üzere birden fazla değerlendirici atanamamıştır. Ayrıca iki değerlendiricinin gözlem yaptıkları sınıfları ve sınıf öğretmenlerini iyi tanımalarının, bu öğretmenlerin sınıf yönetimi becerilerini daha gerçekçi ve doğru olarak değerlendirilmelerini sağlayacağı, böylece SYBKL ile toplanan verilerin daha güvenilir olacağı düşünülmüştür. $\quad \mathrm{Bu}$ nedenle araştırmada verilerin güvenirliği "gözlemler arası güvenirlik" yöntemi ile hesaplanmıştır.

Bu çalışmada sınıf yönetimi becerileri

değerlendiren öğretmenlerin sayısının az olması ve yukarıda açıklanan sınırlılıklarına karşın, çalışmanın, öğretmenlerin önleyici sınıf yönetimine ilişkin fikir verdiği söylenebilir. İleriki çalışmalarda kaynaştırma uygulaması yapılan ve yapılmayan sınıflarda çalışan öğretmenlerin önleyici sınıf yönetimi becerilerinin incelenmesi, bu becerilere etki eden öğretmenin cinsiyeti, yaşı, branş ya da sınıf öğretmeni olması, sınıftaki öğrencilerin özellikleri gibi etmenlerin belirlenerek öğretmenlerin bu konudaki yetkinliklerini artıracak çalışmaların yapılması önerilmektedir. 



\section{KAYNAKLAR}

Ağaoğlu, E. (2001). Sınıf öğretmenlerinin karşılaştıkları istenmeyen öğrenci davranışları ve bu davranışların nedenlerine ilişkin görüşleri ile istenmeyen davranışları önleme yöntemleri. Anadolu Üniversitesi, Bilimsel Araştırma Projeleri, Proje no: 002605, Eskişehir.

Atıcı, M. (2001). Yüksek ve düşük yetkinliğe sahip sınıf öğretmenlerinin sınıf yönetimi stratejileri. Eğitim Yönetimi, 483-499.

Batu, S., \& Özen, A. (1997). Sınıf ögrretmenlerinin sinlf kontrolüne yönelik sorunlarının ve gereksinim duydukları destek hizmet türlerinin belirlenmesi. IV. Ulusal Eğitim Bilimleri Kongresi'nde sunulmuş bildiri, Eskişehir.

Blanton, W., Blanton, L., \& Cross, L. (1993, April). An exploratory study of how expert and novice regular education teachers and special education teachers think and make instructional decisions about special needs students. Paper presented at the meeting of the American Education Research Association, Atlanta.

Büyüköztürk, Ş. (2002). Faktör analizi: Temel kavramlar ve ölçek geliştirmede kullanımı. Eğitim Yönetimi Dergisi, Güz, $470-483$.

Carpenter, S.L., \& McKee-Higgins, E. (1996). Behavior management in inclusive classroom. Remedial \& Special Education, 17(4), 195-206.

Charles, C.M. (1996). Building classroom discipline. New York: Longman Publishers USA.

Çifci, 亡̇., Yıkmıs, A., \& Akbaba-Altun, S. (2001). Kaynaştırma sınıflarında çalışan öğretmenlerin kaynaştırılmış öğrencilere yönelik pekiştireç kullanma durumlarının belirlenmesi. XI. Ulusal Özel Eğitim Kongresi Bildirileri. Konya.

Colvile-Hall, S. (1999). Teaching tolerance, teaching cooperation, conflict resolution, communication and classroom management on the teaching academy project building safe schools. Retrieved December 10, 2004 from http://www. uakoron.edu/education/safesc hools

Darling-Hammond, L. (1996). The quiet revolution: Rethinking teacher development. Educational Leadership, $53,4-10$.

Emmer, E.T., \& Stough, L. M. (2001). Classroom management: A critical part of education. Educational Psychologist, 36(2), Retrieved November 18, 2004 from file://A: \sin.htm

Fitzgerald, J., \& Bass, J. (1997). The frontline of reform: Teachers as implementors of school to work. Educational Forum, 61, 336-342.

Good, T., \& Grouws, D. (1977). Teaching effects: A process product study in fourth grade mathematics classrooms. Journal of Teacher Education, 28(3),4954.

Gordon, T. (1974). Teacher effectiveness training. David McKay.

Hanrahan, J., Goodman, W., \& Rapagna, S. (1990). Preparing mentally retarded students for mainstreaming: Priorities of regular class and special school teachers. American Journal on Mental Retardation, 94, 470-474.

Kameenui, E. J., \& Darch, C.B. (1995). Instructional classroom management: A proactive approach to behavior management. New Jersey: Longman Publishers.

Kounin, J. (1977). Discipline and group management in classrooms. New York: Holt, Rinehart \& Winston. (Orjinal Çalışma 1971'de yayımlanmıştır.)

Long, J.D., Biggs, J.E., \& Hinson, J.T. (1999, June). Perception of education majors and experienced teachers regarding factors that contribute to successful classroom management. Journal of Instructional Psychology. Retrieved November 5, 2004 from, http: //findarticles.Com/p/articles/mi$\mathrm{mOFCO} / \mathrm{is}$ - 2 - 26/ai- 62980749.

Marzano, R.J., \& Marzano, J.S. (2003). The key to classroom management. Educational Leadership, 61(1), 6-17.

Mclntosh, R. (1994). Observations of students with learning disabilities in general education classrooms. Exceptional Children, 60, 249-261. 